Commentary

\title{
The role of CD36 receptor in the phagocytosis of oxidized lipids and AMD
}

\section{Yves Courtois}

\author{
FARVO, CRC INSERM 1990, 75016 Paris, France
}

Commentary on: Shahinaz Picard et al. CD36 plays an important role in the clearance of oxLDL and associated age-dependent sub-retinal deposits. Aging 2010; 2: this issue.

Received: 11/21/10; Accepted: 11/26/10; Published: 11/28/10

Correspondence to: yves.courtois@inserm.fr

(C) Courtois. This is an open-access article distributed under the terms of the Creative Commons Attribution License, which permits unrestricted use, distribution, and reproduction in any medium, provided the original author and source are credited

With the aging of the population in industrialized countries, mechanisms involved in the development of age-related macular degeneration become essential to understand.

AMD is in two forms, a dry or atrophic form and a wet or neovascular form. However, these two forms were characterized in their common early form (also described in aged retina [1]) by the presence of deposits under the retinal pigment epithelium (RPE), in Bruch's membrane (BM; [2]). The origin of drusen is not well established, and several hypothesis are built. Oxidative damage is considered as a major event [3]. Nevertheless, numerous studies using various histological, histochemical and microscopical techniques converge to demonstrate the presence in drusen of esterified and unesterified cholesterol, triglyceride, lipoproteins [4-7].

In this issue of Aging, Picard et al were interested in the mechanism of drusen formation promoting thickening of BM; resulting in decrease in RPE permeability and therefore a failure to transport nutrients from the RPE to photoreceptors, resulting in theirs deaths [8-9].

Picard et al. confirmed the results already foreshadowed by other teams that the cells of RPE are able to up-take and internalize oxidized lipids (oxLDL) via scavenger receptor CD36 [10]. The same team had previously shown that CD36 deficiency leads to choroidal involution [11]. In this new paper, the authors demonstrated that aged-mice deficient in CD36 have thickening of BM with formation of sub-RPE deposits such as "drusen". Using a model often used for studies on atherosclerosis, ApoE-/- mice, they confirmed that CD36 deficiency increases BM thickness [12] and correlated this with increased plasma oxLDL level.

So it seems that the CD36 receptor deficiency has a role in the formation of deposits due to lipid excess during aging [13] under RPE, resulting in a breakdown between the bloodstream (choroicapillaries) and RPEphotoreceptors $[14,15]$. They also demonstrated that this phenomena may be partially restored by stimulating the expression of CD36 with a peptide derived of growth hormone.

To conclude, the study of Picard et al. highlighted the important role of CD36 in maintaining homeostasis of the pigmented epithelium. CD36 deficiency in aging and more severely during the early stage of AMD [16] associated with a cumulative effect of oxidative stress could be one of the primordial players in the development of late stages of the disease.

\section{REFERENCES}

1. Pauleikhoff D, Harper CA, Marshall J, Bird AC. Aging changes in Bruch's membrane. A histochemical and morphologic study. Ophthalmology. 1990; 97: 171-178.

2. Green WR and Enger C. Age-related macular degeneration histopathologic studies. The 1992 Lorenz E. Zimmerman Lecture. Ophthalmology. 1993; 100: 1519-1535.

3. Shen J, Dong A, Hackett SF, Bell WR, Green W et al. Oxidative damage in age-related macular degeneration. Histol Histopathol. 2007; 22, 1301-1308.

4. Curcio, Millican CL, Bailey T, Kruth HS. Accumulation of chole- 
sterol with age in human Bruch's membrane. Invest Ophthalmol Vis Sci. 2001; 42: 265-274.

5. Huang JD, Curcio CA, Johnson M. Morphometric analysis of lipoprotein-like particle accumulation in aging human macular Bruch's membrane. Invest Ophthalmol Vis Sci. 2008; 49: 2721272.

6. Li CM, Chung BH, Presley JB, Malek G, Zhang X et al. Apolipoprotein localization in isolated drusen and retinal apolipoprotein gene expression. Invest Ophthalmol Vis Sci. 2006; 47: 31193128.

7. Wang L, Leitner WP, Rivest AJ, Staples MK, Radeke MJ et al. Abundant lipid and protein components of drusen. PLoS One. 2010; 5: e10329.

8. Johnson PT, Leitner WP, Rivest AJ, Staples MK, Radeke MJ et al. Synaptic pathology, altered gene expression, and degeneration in photoreceptors impacted by drusen. Invest Ophthalmol Vis Sci. 2005; 46: 4788-4795.

9. Rodriguez IR, Alam S, Lee JW. Cytotoxicity of oxidized lowdensity lipoprotein in cultured RPE cells is dependent on the formation of 7-ketocholesterol. Invest Ophthalmol Vis Sci. 2004; 45: 2830-2837.

10. Gordiyenko N, Campos M, Lee JW, Fariss RN, Sztein J et al. RPE cells internalize low-density lipoprotein (LDL) and oxidized LDL (oxLDL) in large quantities in vitro and in vivo. Invest Ophthalmol Vis Sci. 2004; 45: 2822-2829.

11. Houssier M, Raoul W, Lavalette S, Keller N, Guillonneau X et al. CD36 deficiency leads to choroidal involution via COX2 downregulation in rodents. PLoS Med. 2008; 5: e39.

12. Ong JM, Zorapapel NC, Rich KA, Wagstaff RE, Lambert RW et al. Effects of cholesterol and apolipoprotein $E$ on retinal abnormalities in ApoE-deficient mice. Invest Ophthalmol Vis Sci. 2001; 42: 1891-18900.

13. Parekh N, Voland RP, Moeller SM, Blodi BA, Ritenbaugh C et al. Association between dietary fat intake and age-related macular degeneration in the Carotenoids in Age-Related Eye Disease Study (CAREDS): an ancillary study of the Women's Health Initiative. Arch Ophthalmol. 2009; 127: 1483-1493.

14. Moore DJ, Hussain AA, Marshall J. Age-related variation in the hydraulic conductivity of Bruch's membrane. Invest Ophthalmol Vis Sci. 1995; 36: 12901297.

15. Starita C, Hussain AA, Pagliarini S, Marshall J. Hydrodynamics of ageing Bruch's membrane: implications for macular disease. Exp Eye Res. 1996; 62: 565-572.

16. Kondo N, Honda S, Kuno S, Negi A. Positive association of common variants in CD36 with neovascular age-related macular degeneration. Aging. 2009; 1: 266-274. 